Please do not remove this page

RMIT

UNIVERSITY

\title{
Fire or ice: A critical assessment of the underlying views
}

Burns, Kelly; Moosa, Imad

https://researchrepository.rmit.edu.au/esploro/outputs/9921859438301341/filesAndLinks?institution=61RMIT_INST\&index=null

Burns, K., \& Moosa, I. (2013). Fire or ice: A critical assessment of the underlying views. Journal of Reviews on Global Economics, 2, 123-130. https://doi.org/10.6000/1929-7092.2013.02.10

Document Version: Published Version

Published Version: https://doi.org/10.6000/1929-7092.2013.02.10

Repository homepage: https://researchrepository.rmit.edu.au

(C) 2013 Lifescience Global

Downloaded On 2023/04/26 23:56:31 +1000

Please do not remove this page 
Thank you for downloading this document from the RMIT Research Repository.

The RMIT Research Repository is an open access database showcasing the research outputs of RMIT University researchers.

RMIT Research Repository http://researchbank.rmit.edu.au/

\section{Citation:}

Burns, K and Moosa, I 2013, 'Fire or ice? A critical assessment of the underlying views', Journal of Reviews on Global Economics, vol. 2, pp. 123-130.

See this record in the RMIT Research Repository at:

https://researchbank.rmit.edu.au/view/rmit:22785

Version: Published Version

Copyright Statement: (c) 2013 Lifescience Global

This is an open access article licensed under the terms of the Creative Commons Attribution Non-Commercial License

Link to Published Version: (http://creativecommons.org/licenses/by-nc/3.0/)

http://dx.doi.org/10.6000/1929-7092.2013.02.10 


\title{
Fire or Ice? A Critical Assessment of the Underlying Views
}

\author{
Kelly Burns* and Imad Moosa
}

\begin{abstract}
School of Economics, Finance and Marketing, RMIT, Australia
Abstract: A debate is raging on whether the U.S. is likely to experience hyperinflation (fire) or deflation (ice) as a result of post-crisis policies, particularly quantitative easing. Views have been put forward to suggest that the U.S. is heading towards ice, while others suggest that fire is the destination. There are also those who envisage either fire or ice, depending on how much is done to combat deflation. These views are assessed critically to reach the conclusion that, on the balance of probabilities, it seems that the U.S. is more likely heading towards fire.
\end{abstract}

Keywords: Hyperinflation, Quantitative Easing, Deflation.

\section{INTRODUCTION}

A debate is currently raging about whether the U.S. economy (and the economies of other OECD countries) are heading towards deflation (ice) or hyperinflation (fire). In the aftermath of the global financial crisis and the recession that followed, central banks (particularly the Federal Reserve) started to pump liquidity into the system via quantitative easing, a form of monetary policy whereby the central bank buys government bonds with freshly-created money. While it is only natural to think that a monetary expansion caused by quantitative easing will eventually lead to inflation, some economists believe that quantitative easing will actually lead to deflation. Others, guided by the Japanese experience, believe that it will be deflation with or without quantitative easing. Some economists think that both outcomes are possible, depending on the current and future actions of policy makers. Duncan (2012), for example, concludes that the price level could either collapse or surge higher, depending on whether governments cease quantitative easing or, by attempting to prevent deflation, maintain quantitative easing, thus generating hyperinflation. Likewise Bourque (2012) argues that "whether we have inflation or deflation depends on just how much governments are willing to do to prevent deflation".

The objective of this paper is to examine critically the views put forward about this issue, concentrating on the U.S. economy, which has witnessed the most aggressive rounds of quantitative easing. We will examine the arguments for ice, the arguments against fire and the arguments for fire. As a starting point, and to put things into perspective, a brief description of quantitative easing is presented.

*Address correspondence to this author at the RMIT, School of Economics, Finance and Marketing, 445 Swanston Street, Melbourne, Victoria 3000, Australia; Tel: +61 39925 5640; Fax: +61 39925 5624;

E-mail: kelly.burns@rmit.edu.au

\section{QUANTITATIVE EASING}

Quantitative easing has become common in the aftermath of the global financial crisis and the Great Recession. The practice involves the creation of money and injecting it into the domestic economy, typically by the Fed buying securities from banks and other financial institutions. The underlying idea is that the new money will flow (in the form of loans) from banks to other areas of the economy, boosting production and employment.

While central bankers indulging in quantitative easing portray the practice as being benign at worst and necessary at best, most commentators are sceptical of the official line of thinking. For example, in its description of quantitative easing, the Bank of England claims that it does not involve printing banknotes, to give the impression that the policy has no inflationary consequences. ${ }^{1}$ However, there is no difference (as far as the inflationary consequences of the policy are concerned) between creating money by printing physical notes and by doing it electronically-in both cases the subsequent increase in purchasing power is bound to boost inflation.

Central bankers also stress the distinction between creating money to buy financial assets and to buy goods and services, the latter representing a monetization of the deficit. The underlying idea is that buying bonds from banks is different from buying bonds directly from the government-only the latter constitutes a monetization of the deficit. Ben Bernanke, for example, remarked once that the government would not print money and distribute it "willy nilly" but would rather focus its efforts in certain areas (for example, buying federal agency debt securities and mortgage-

\footnotetext{
${ }^{1}$ http://www.bankofengland.co.uk/monetarypolicy/Pages/qe/default.aspx.
}

(c) 2013 Lifescience Global 
backed securities) (Wolf, 2008). According to Robert McTeer, a former president of the Federal Reserve Bank of Dallas, "there is nothing wrong with printing money during a recession, and quantitative easing is different from traditional monetary policy only in its magnitude and pre-announcement of amount and timing" (McTeer, 2010). However, Richard Fisher, the current president of the Federal Reserve Bank of Dallas, warns of "the risk of being perceived as embarking on the slippery slope of debt monetization", suggesting that "once a central bank is perceived as targeting government debt yields at a time of persistent budget deficits, concern about debt monetization quickly arises" (Fisher, 2010). He reaches the conclusion that the Fed is monetizing government debt. In the new edition of his famous book "When Money Dies", Fergusson describes quantitative easing as a "modern euphemism for surreptitious deficit financing in an electronic era", which "can no less become an assault on monetary discipline" (2010:276).

Ringer (2009) describes quantitative easing as a "dumb and idiotic venture", considering the "venture" as signalling a hyperinflationary strike. There is, however, an element of truth in the claim that quantitative easing is intended revive the economy, except that no central banker would say explicitly how it is intended to do that. One way to encourage consumption is to boost inflationary expectations-so perhaps the main objective of quantitative easing is that (boosting inflationary expectations). Krugman (2012) argues that higher inflation in the U.S. would be beneficial in alleviating private debt and encouraging consumption and thus recovery. According to Krugman, it is the overhang of private sector debt (accumulated during the 'bubble years') that continues to cripple private spending and perpetuate the economic downturn. Higher inflation would "erode the real value of this debt, deter the private sector from hoarding its current cash reserves and therefore promote consumption, investment and economic recovery". So quantitative easing may be a deliberate policy action taken to create inflation and debase the dollar.

Krugman is not alone in supporting quantitative easing. In an IMF staff position note, Klyuev et al. (2009) report that quantitative easing measures undertaken by the central banks of major developed countries have reduced systematic risk in the banking system, improved market confidence and assisted in relieving the economic downturn. Other economists argue that quantitative easing will lead to a host of serious economic problems and that the appropriate policy tool is fiscal rather than monetary policy. In an open letter to Ben Bernanke, Asness et al. (2010) argue that fiscal policies (in particular improvements in tax and spending) are the appropriate tools to help restore the economy. Unlike Krugman (2012) these economists disagree with the view that inflation needs to be pushed higher and argue that quantitative easing is distorting financial markets. In this sense, "quantitative easing by the Fed is neither warranted nor helpful in addressing either U.S. or global economic problems". Likewise, Stiglitz (2012) argues that the type of stimulus needed to restore the economy is fiscal stimulus and financial sector reforms designed to boost lending. According to Stiglitz, the announcement of QE3 provided a clear signal about the effectiveness of quantitative easing as a policy tool.

The Fed repeatedly says that it can reverse quantitative easing whenever it wishes by selling the bonds it has already acquired. This sounds like an alcoholic declaring with a high degree of confidence that he or she can quit booze any time. Just like quitting booze is not easy for an alcoholic, stopping quantitative easing is not easy for the Fed if "stopping" involves selling the accumulated trillions of dollars worth of Treasuries. It will be a task of monumental proportions to find buyers under the present and anticipated circumstances. The Economist (2011) makes it clear that "it is easy to start quantitative easing but difficult to get out of it". If the Fed cannot sell the Treasury bonds it has acquired from banks, that will be effectively a monetization of the deficit.

\section{ARGUMENTS FOR ICE}

Arguments for ice are based on the proposition that the economy is already pushing towards a debt deflationary depression as a result of an extended credit bubble. The bursting of the bubble will reduce the velocity of circulation of money, thereby causing downward pressure on prices. High unemployment coupled with large and growing amounts of government debt is said to indicate that deflation and a subsequent depression will occur. Since the Fed cannot continue to inflate the money supply via quantitative easing, austerity measures become unavoidable. The problem with this argument is that in the age of computergenerated fiat money, there is no limit on the ability of the Fed to inflate the money supply. Abandoning quantitative easing can only be triggered by the realization that the inflation risk is high, which is why the Bank of England abandoned the policy in May 2012, and/or the realization that it is ineffective. 
According to the theory of debt deflation of Fisher (1933), an economic depression is the result of the credit cycle, as a reduction in debt results in an economic downturn. Fisher postulated that the end of a debt bubble leads to a liquidation of assets and distress selling. As loans are paid off, the velocity of circulation declines, causing a fall in prices and subsequently shrinking output and employment. Deflation is a characteristic of severe economic downturn where high unemployment means that governments find it difficult to control debt in the face of falling prices and wages, and hence tax revenue. This is probably what happened in the 1930s but there is a big difference between the 1930s and the present time. In the 1930s the U.S. money supply contracted by about one thirdtoday it is rising very rapidly as the Fed indulges in quantitative easing.

A proposition has been put forward suggesting that ice will be the very outcome of quantitative easingthat quantitative easing will cause deflation. The underlying idea is that by reducing returns on government bonds, quantitative easing will curtail the consumption of those receiving interest income such as annuities. For example, Stiglitz (2012) argues that quantitative easing will punish consumers invested in government bonds and curtail their consumption. Reduced consumption and hoarding of cash by these sectors of the economy will produce deflation, a situation that is exacerbated by an ageing population. According to Nevin (2012) quantitative easing in the U.K. failed because the negative impact on annuity rates forced consumers and investors to hoard cash reserves. It is also argued that quantitative easing can impact consumer and producer sentiment negatively, which promotes a deflationary environment. McTeer (2010), for example, argues that the use of the term "quantitative easing" has a significant impact on consumer confidence that drives down stock prices, giving rise to an adverse wealth effect. This argument is not convincing in the sense that low interest rates should encourage consumption rather than the other way round. The reason why this is not happening is the classic "you can take the horse to the water but you cannot force it to drink". ${ }^{2}$ Furthermore, there are two reasons why low interest rates are unlikely to have an adverse effect on consumption. The first is that low interest rates provide a boost for the bond market,

\footnotetext{
${ }^{2}$ That is, low interest rates do not represent a necessary and sufficient condition for increased demand for credit and a consequent boost to production and employment.
}

creating a positive wealth effect. The second is that income derived from interest payments represent a small fraction of the total economy compared to wages and salaries.

Some observers contend that the U.S. economy is already in a deflationary phase and that quantitative easing is merely postponing an inevitable debtdeflation depression. The deflationary depression, according to this argument, is inevitable because large amounts of government debt mean that quantitative easing is not sustainable. Chapman (2010) cites evidence indicating that the U.S. has been in a deflationary state since 2002 and that the provision of massive amounts of money and credit via quantitative easing is merely postponing a deflationary depression. The indicators for this state of affairs include depressed consumption, close to zero interest rates, a high unemployment rate and a weak dollar. Bourque (2012) argues that the world is already in a deflationary economic period as a result of "too much government and personal debt, hyper-speculation and aging baby boomers moving beyond their peak spending years". He argues that the contraction of the world economy is being fended off by governments that are trying to secure their positions by quantitative easing measures that are intended to "shake the world out of its deflationary mood".

Several economists put forward the argument that as soon as large amounts of government debt make quantitative easing no longer viable, deflation and economic downturn will follow. Chapman (2010) argues that the continued creation of government debt and monetization of the deficit by the Fed means that "a deflationary collapse, one way or another, is inevitable". Duncan (2012) argues that current economic conditions are similar to those that resulted in the Great Depression (caused by large fiat-moneydenominated credit bubbles) which were described by Fisher (1933) as debt-deflation dynamics. These conditions threaten a "New Great Depression" should government intervention cease. He goes on to say that as soon as the government withdraws stimulus or "the governments capacity to provide any more stimulus is exhausted....the deflationary death spiral will resume" (Duncan 2012:155). Two points are noteworthy here, albeit at the risk of repetition. The first is the big difference between the Great Depression and the current situation (monetary contraction versus expansion). The second is that there is no limit on the provision of money via quantitative easing - money can be created at the click of a mouse. 
Another proponent of the ice view is Mankiw (2010) who is more worried about deflation and stagnation than about excessive inflation. The IMF (2012) warns of a "sizeable risk" of deflation and estimates a 25 percent probability of below zero inflation by early 2014. Some economists consider headline CPI figures as providing evidence for the proposition that deflation is more likely than inflation in the imminent future (McTeer, 2010).

One justification for the ice view is that quantitative easing has been ineffective in stimulating the economy. This means that the realization of the ineffectiveness of quantitative easing will force its abandonment, leading to deflation. This view, however, does not reflect the current state of affairs. The initiation of QE3 in September 2012 indicates the belief (of the Fed) that quantitative easing can and does work. On 12 December 2012 Bernanke announced that quantitative easing will be maintained at the rate of $\$ 85$ billion per month until unemployment falls below 6.5 percent (Fontevecchia, 2012). ${ }^{3}$ Given how sluggish the unemployment rate is, quantitative easing will be maintained for a very long time if the unemployment target is to be achieved.

\section{ARGUMENTS AGAINST FIRE}

Some commentators argue that hoarding of excess bank reserves will neutralize the potential for inflation as the increase in the money supply will be offset by a reduction in velocity. Wade and Bilson (2012) suggest that hyperinflation is not currently a threat in the U.S. because the increase in the monetary base via quantitative easing (which has at least doubled) has been matched by huge reductions in the velocity of circulation. Holland (2012) states that "printing money doesn't necessarily fuel inflation, especially when people are paying down debt and banks are reluctant to create new credit". McTeer (2010) contends that the large expansion of the Fed's balance sheet remains as excess reserves, which are not used for moneycreating lending and investing. He concedes that excess bank reserves (while potentially inflationary) are currently not. The accumulation of reserves reflects the conservative lending nature of bankers and the slowdown in demand from creditworthy borrowers. O'Brien (2012) argues that quantitative easing is not really printing money, but rather swapping one asset (cash) for another (bonds). Thus, "whatever money the

\footnotetext{
${ }^{3}$ This move has been dubbed "QE4"
}

Fed prints is stuck in the banks". That money, according to O'Brien, "isn't inflationary as long as the banks don't lend it out". If banks decided to lend the money out, the Fed can respond by "raising the interest on excess reserves or require the banks to set aside more money".

It is true that the massive expansion of the monetary base has not (yet) resulted in a corresponding expansion in the money supply, a situation that can be explained in terms of the simple money multiplier model. However, this situation is unsustainable because the current reserves to checkable deposits ratio is greater than one. Banks will go out of business if they do not lend-after all they are in the money lending business. The situation is already changing, which is confirmed by the figures provided by the Federal Reserve Bank of St Louis. In October 2012 reserves with the Fed declined by almost 4 percent, a massive monthly figure. In the same month the narrow money supply rose by over 3 percent. The proposition that the Fed can respond to an increase in lending by raising interest rates will be counterproductive from the Fed's perspective. Quantitative easing and Operation Twist have been implemented for the very reason of keeping interest rates low. And because banks' reserve ratio is extremely high, there is no scope for the Fed to raise reserve requirements.

Several commentators argue that quantitative easing is not going to lead to inflation because of the currently underutilized productive capacity and high unemployment rate. Stiglitz (2012) argues that QE3 will not cause "serious" inflation because of the economy's underutilized productive capacity. Levine-Weinberg (2012) similarly argue that quantitative easing will not cause hyper (or even severe) inflation because of a high unemployment rate in the U.S. Harvey (2011) points out that there is no reason why quantitative easing will not lead to a rise in production and employment as opposed to prices, as long as excess money balances are invested in productive activities to meet the new demand. This line of thinking is flawed because it does not distinguish between moderate inflation and hyperinflation. Reference to spare capacity and unemployment implies that what these economists have in mind is moderate demand-pull inflation. What we are talking about here is hyperinflation, which is not an extension of moderate inflation. While moderate inflation can be attributed to demand-pull factors, hyperinflation is a fiscal-monetarypolitical problem that could arise irrespective of the cyclical state of the economy. 
O'Brien (2012) argues that "fears of hyperinflation in the United States are almost certainly unfounded" because "the countries that have suffered the pain of a worthless currency share very little with the United States". Hyperinflation, O'Brien argues, is typically associated with war, revolution or terribly bad economic policy (such as the land reform in Zimbabwe)-these are not characteristics of the U.S. However, O'Brien also suggests that "the economic collapse begets a collapse in tax revenues", which "makes the government look like a terrible credit risk". This government will be "cut off from international lenders...left with a gaping hole in its budget, and no way to fill it". According to O'Brien, the U.S. is in a different position because the U.S. (i) does not have any problems selling sovereign debt, and (ii) has a highly productive and functioning economy. On the first point, O'Brien argues that unlike Hungary in the 1940s, investors are scrambling to buy Treasuries even though interest rates are very low. On the second point, he argues that "it's very difficult to have hyperinflation when you still have a functioning economy".

It is not difficult to respond to O'Brien's arguments because they are intuitively and factually flawed. The U.S. may not have a problem selling sovereign debt for the time being for several reasons, the two most important being the situation in Europe and the Basel accords that encourage the holding of sovereign debt by financial institutions. At one time, Greece had no problem selling sovereign debt but things have changed dramatically as we all know. It is not about the situation now-it is about the fact that the U.S. has already begun the journey towards hyperinflation. Major holders of U.S. Treasuries have already lost their appetite for financing the U.S. fiscal deficit. For example, the biggest foreign holder of Treasury securities, China, reduced its holdings by $9 \%$ between September 2011 and September 2012. Other countries reduced their holdings over the same period: OPEC countries (0.8\%), Brazil (3.6\%), Caribbean countries (8.9\%), Hong Kong (4\%), UK (3.6\%), France (7.9\%), and Denmark (4.4\%). The figures do not indicate any "scrambling to buy Treasuries" as O'Brien claims. Given also the stock of Treasuries accumulated by the Fed as a result of quantitative easing, there seems to be a glut of Treasuries. It will become increasingly difficult to sell U.S. government debt.

Furthermore O'Brien seems to confuse the cause and the effect when he argues that "it is very difficult to have hyperinflation when you still have a functioning economy". It is hyperinflation that transforms a functioning economy into a devastated one. It could happen in a functioning economy if the budget deficit is financed by creating money. Israel certainly had a functioning economy in the 1980s but it experienced hyperinflation. Furthermore, hyperinflation is not necessarily associated with war and revolutionMexico, Brazil and Argentina had it without war or revolution. If anything, the U.S. is currently at war and spending excessively on the military.

\section{ARGUMENTS FOR FIRE}

According to Bourque (2012), the U.S. is engaging in excessive quantitative easing, forcing hyperinflation as a potential outcome. In an open letter to Ben Bernanke, several leading economists warned that the planned asset purchases by the Fed "risk currency debasement and inflation" and will not achieve its objective of promoting full employment (Asness et al., 2010). Wade and Bilson (2012) suggest that there are legitimate concerns over the impact of the huge expansion in the monetary base and greater velocity, which trigger the potential for inflation to overshoot targets in the medium term. Wade and Bilson (2012) caution that "expected inflation remaining low relies on the faith people have in policymakers" and that consumer and business sentiment can change rapidly. Inflationary expectations remain a threat because policy makers are considering an increase in the inflation target or greater tolerance for being above target (see, for example, Blanchardet al., 2010).

Sound arguments can be put forward for why the U.S. will experience hyperinflation sooner or later because it has gone so far down the path towards hyperinflation. An annual budget deficit in excess of one trillion dollars requires the federal government to sell bonds for the amount of the deficit plus any bonds coming due. ${ }^{4}$ Investors are mostly buying short-term bonds, so the Fed will buy any bonds not bought by anyone else. The federal government will make sure that will happen even if it requires changing the laws governing the Fed or the people running it. Right now Bernanke seems to be compliant. Government spending is out of control and the Fed will keep creating money as fast as the government needs.

While O'Brien (2012) rules out the possibility of hyperinflation in the U.S. by using flawed arguments,

\footnotetext{
${ }^{4}$ If the deficit is calculated on a GAAP basis and by taking into account changes in the net present value of unfunded liabilities, the deficit can be as big as $\$ 5$ trillion (Williams, 2012).
} 
his description of the circumstances under which hyperinflation occurs is perfectly applicable to the U.S. $\mathrm{He}$ refers to (i) a collapse in tax revenue, (ii) the government looking like a terrible credit risk, (iii) a gaping hole in the budget, (iv) piles of foreign debt, and (v) a big chunk of the available cash is earmarked for foreign creditors. These are either current symptoms of the U.S. economy or it is heading that way.

The hyperinflation sceptics may say that the U.S. is currently going through what Japan has been experiencing in the last two decades-after all it was the Japanese who invented quantitative easing more than twenty years ago. Japan is not experiencing hyperinflation but rather deflation. While there is an element of truth in this claim, there is a big difference: Japanese sovereign debt is more stable than that of the U.S. because it is held mostly by Japanese citizens, which makes Japan less vulnerable than the U.S. to the changing sentiment of foreign creditors. Hence Japan is less likely to monetize its deficit than the U.S. However, an adverse development in Japan will force the Japanese to off-load their holdings of U.S. Treasuries, causing further funding problems for the U.S.

Apart from economic indicators, theory and history seem to support the fire view. Let us start with the theory of hyperinflation. In the crisis of confidence model of hyperinflation, the loss of confidence comes before and also causes monetary growth. In the monetary model, rapid monetary growth comes first and causes the loss of confidence. So, it is either that too little confidence forcing an increase in the money supply, or too much money destroying confidence. The status quo is that confidence in the dollar is dwindling for reasons other than quantitative easing, but quantitative easing is causing the process to accelerate. Loss of confidence in the dollar comes partly from the collective desire to kill the exuberant privilege that the U.S. has enjoyed since the end of World War II.

There are three dimensions to the loss of confidence in the dollar: (i) the international reserve status, (ii) the currency to which currencies under fixed exchange rate are pegged to, and (iii) the currency of invoicing and the medium of exchange in the international trade of commodities. As far as the first dimension is concerned, countries like China, Russia and France are just three examples of countries that have been demanding the replacement of the dollar with something else. International organizations such as the IMF and UNCTAD (United Nations Council of Trade and Development) share this view and so do a number of eminent economists, including Joseph Stiglitz. How this is related to the possibility of hyperinflation is intuitively simple. As countries refrain from accumulating dollar-denominated reserve assets (such as Treasuries) the Fed will find it increasingly difficult to raise funds by borrowing, not to mention that it will be difficult to reverse quantitative easing by offloading the government securities it has already acquired. The printing press (or the computer) will be the last resort.

On the second dimension, countries that peg their currencies to the dollar tend to experience imported inflation as the dollar depreciates against other currencies-again thanks to quantitative easing. Most of the inflation experienced in the Gulf oil exporting countries, which peg to the dollar, has been brought about by the weakening of the dollar. At least one of these countries (Kuwait) has already abandoned the dollar peg for a basket peg. Others are likely to follow. By abandoning the dollar peg, these countries will not need to accumulate dollar-denominated assets.

The third dimension is that the dollar may lose its status as the currency of invoicing and settlement in international trade, particularly commodities (most notably, oil). It is strange that some observers claim that it would take the oil-exporting Gulf states many years to replace the dollar as the currency oil is priced in. This is a peculiar claim since Iran switched to nondollar sales in a short time. As should be expected with a depreciating dollar, Iran has declared that it has profited from switching to non-dollar oil sales. Other countries can see this benefit and switch quickly too. OPEC is reportedly looking to price oil in something other than the U.S. dollar (Gold Report, 2010). The Gulf states have been for some time now thinking about a common currency. Given the small volume of intra-regional trade and investment, a common currency will not be beneficial unless these countries use it as the currency of invoicing and settlement in oil trade.

As for history, the U.S. is showing the same symptoms as those emerging in hyperinflationary episodes. The following causes of hyperinflation are applicable to the U.S. economy: (i) excessive military spending; (ii) monetization of the deficit; (iii) the desire to revive the economy, because this is the declared objective of quantitative easing; (iv) spending to bail out financial institutions under the notorious pretext of "too 
big to fail"; (v) external borrowing to fund the fiscal gap; (vi) populist policies such as the funding of projects under the fiscal stimulus scheme and feet-dragging over the real problem of unfunded Medicare/Medicade and social security liabilities; and (vii) a political framework whereby it is difficult to sort out the fiscal mess.

Dowd et al. (2011) portray a picture of how hyperinflation will hit the U.S., arguing that "if the Fed persists along its declared path, the prognosis is accelerating inflation leading ultimately to hyperinflation and economic meltdown". They predict that the Fed will be forced to monetize the whole of the federal debt, which requires a rapid expansion of the monetary base. For them, hyperinflation in the U.S. is inevitable.

\section{CONCLUSION}

A debate is raging on whether the U.S. is heading for hyperinflation (fire) or deflation (ice) as a result the post-crisis policies, particularly quantitative easing. Some economists predict ice on the grounds that quantitative easing is just delaying the inevitable. Others argue that quantitative easing will cause deflation because of adverse income and wealth effects. Another group of economists argue that ice will materialize with or without quantitative easing-indeed some believe that the U.S economy is already experiencing deflationary conditions. Some of these arguments are flawed because they overlook the facts that in the age of compuer-generated money there is no limit on quantitative easing, that the conditions prevailing today are different from the conditions prevailing in the 1930s and because it is implausible that the low interest rates produced by quantitative easing have a negative impact on consumption.

Arguments against fire are also flawed because of the assumption that quantitative easing has no inflationary consequences. The argument that fire is not a potential outcome because of excess capacity and unemployment confuses mild inflation with hyperinflation. The argument that the U.S. is different from the countries that have experienced hyperinflation in the past is not strictly valid, neither is the argument that hyperinflation is typically associated with war or revolution. On the other hand, theory, historical experience and economic indicators provide convincing reasoning to support the proposition that the U.S. is heading towards fire. On the balance of probabilities we conclude that the pro-fire camp is winning the debate.

\section{REFERENCES}

Asness, Cliff, Michael J. Boskin, Richard X. Bove, Charles Calomiris, Jim Chanos, John Cogan, Niall Ferguson, Nicole Geina, James Grant, Kevin A. Hassett, Roger Hertog, Gregory Hess, Douglas Holtz-Eaking, Seth Klarman, William Kristol, David Malpass, Ronald I. McKinnon, Dan Senor, Amity Shlaes, Paul E. Singer, John B. Taylor, Peter J. Wallison and Geoffrey Wood. 2010. Pen Letter to Ben Bernanke, Wall Street Journal Blogs, 15 November.

Blanchard, Olivier, Giovanni Dell'Aricciaand Paolo Mauro. 2010. Rethinking Macroeconomic Policy, IMF Staff Note, 12 February 2010 SPN/10/03

Bourque, Gary. 2012. Fire or Ice? Inflation or Deflation? Four Minute Finance, 26 September 2012.

Chapman, Bob. 2010. Quantitative Easing, Inflation, Hyperinflation and Global Deflationary Depression, Global Research, 17 October.

Duncan, Richard. 2012. The New Depression: The Breakdown of the Paper Money Economy, Wiley.

Fergusson, Adam. 2011. When Money Dies: The Nightmare of Deficit Spending, Devaluation, and Hyperinflation in Weimar Germany. Scribe Publications.

Fisher, Irving. 1933. The Debt Deflation Theory of the Great Depression, Econometrica 1: 337-57. http://dx.doi.org/10.2307/1907327

Fisher, W. Richard. 2010. Speeches by Richard W. Fisher, Federal Reserve Bank of Dallas. http://dallasfed.org/news/speeches/ fisher/2010/fs 101108.cfm (accessed on 08/11/2012).

Fontevecchia, Agustino. 2012.QE4 Is Here: Bernanke Delivers \$85BA-Month Until Unemployment Falls Below 6.5\%, Forbes, 12 December. http://www.forbes.com/sites/afontevecchia/2012/ 12/12/qe4-is-here-bernanke-delivers-85b-a-month-untilunemployment-falls-below-6-5/ (accessed on 16/12/2012)

Harvey, T. John. 2011. Money Growth Does Not Cause Inflation!, Forbes, 15 May.

Holland, Tom. 2012. Warning: Quantitative Easing Could End up Causing Deflation, South China Morning Post, 19 September.

IMF. 2012. Euro Area Policies, IMF Country Report No.12/181, July.

Klyuev, Vladimir, Phil De Imusand Krishna Srinivasan. 2009. Unconventional Choices for Unconventional Times: Credit and Quantitative Easing in Advanced Economies, IMF Staff Position Note, 4 November, SPN/09/27

Krugman, Paul. 2012. Not Enough Inflation, New York Times, 5 April.

Levine-Weinberg, Adam. 2012. Why I'm Not Afraid of QE3, Seeking Alpha, 13 September.

Mankiw, Gregory. 2010. QE2, Greg Mankiw's Blog Random Observations for Students of Economics, 17 November.

McTeer, Bob. 2010. Monetary Policy, Deflation And Quantitative Easing, Forbes StreetTalk, 30 July.

Nevin, Michael. 2012. The Golden Guinea: The International Financial Crisis, 2007-2004: Causes, Consequences and Cures, Southdown Books.

O'Brien, Matthew. 2012. The Hyperinflation Hype: Why the U.S. Can Never Be Weimar, 21 March. http://www.theatlantic.com/ business/archive/2012/03/the-hyperinflation-hype-why-theus-can-never-be-weimar/254715/ (accessed 09/11/2012). .

Ringer, Roger. 2009. Hyperinflation and the Changes it is Going to Generate, 21 May. http://www.tacticalinvestor.com/ hyperinflation1.html (accessed 28/11/2012).

Stiglitz, Joseph. 2012. Quantitative Easing Won't Cause Inflation, But That's Not Good News, Slate Magazine, 7 October.

The Economist. 2011. Stopping Quantitative Easing May be Harder than Starting it, 19 March. 
Wade, Keith and James Bilson. 2012. Will Quantitative Easing Lead to Higher Inflation? Schroders TalkingPoint, June.http://www. schroders.com/staticfiles/Schroders/Sites/Americas/US\%20I nstitutional\%202011/pdfs/Talking-Point-QE-Inflation.pdf (accessed 01/12/2012)
Williams, John. 2012. Hyperinflation 2012, American Business Analytics and Research, Special Commentary Number 414: 25.

Wolf, Martin. 2008. 'Helicopter Ben' confronts the challenge of a lifetime, Financial Times, 16 December.

DOI: http://dx.doi.org/10.6000/1929-7092.2013.02.10

(c) 2013 Burns and Moosa; Licensee Lifescience Global.

This is an open access article licensed under the terms of the Creative Commons Attribution Non-Commercial License (http://creativecommons.org/licenses/by-nc/3.0/) which permits unrestricted, non-commercial use, distribution and reproduction in any medium, provided the work is properly cited. 